\title{
Hubungan Antara Peran Perawat Sebagai Educator dengan Motivasi Sembuh Pasien Tuberkulosis di Wilayah Kerja Puskesmas Woha
}

\author{
Junaidin \\ STIKES YAHYA BIMA \\ Email : junaidinstikesyahya@gmail.com
}

\begin{abstract}
ABSTRAK : Tuberkulosis adalah penyakit infeksi kronis yang masih merupakan permasalahn serius yang di temukan pada penduduk dunia termasuk Indonesia. Motivasi pasien untuk sembuh mempengaruhi faktor lingkungan rumah sakit, dokter, perawat dan tenaga kesehatan lainnya serta dukungan dari keluarga Tujun dari penelitian ini adalah untuk melihat Hubungan Peran Perawat Dan Keluarga Sebagai Educator Dengan Motivasi Sembuh Pasien Tuberkulosis Di Puskesmas Woha Tahun 2019. Penelitian ini menggunakan cross sectional . populasi penelitian ini sejumlah 90 orang. Teknik pengambilan sampel menggunakan Proposive Sampling dengan jumlah sampel sebanyak 32 orang dan menggunakan Uji Chi-Square. Instrumen dalam penelitian ini menggunakan kuesioner. Hasil analisa peran perawat diperoleh nilai pValue $=0,03<\alpha 0,05$, artinya ada hubungan peran perawat sebagai educator dengan motivasi sembuh pasien. Hasil analisa peran keluarga diperoleh nilai pValue $=0,006<\alpha 0,05$, artinya ada hubungan peran keluarga sebagai educator dengan motivasi sembuh pasien, artinya ada hubungan peran perawat dan keluarga sebagai educator dengan motivasi sembuh pasien tuberkulosi di Puskesmas Woha Tahun 2019. Kesimpulan dari penelitian ini adalah ada hubungan yang signifikan antara peran perawat dan keluarga sebagai educator dengan motivasi sembuh pasien di Puskesmas Woha Tahun 2019. Untuk itu upaya pencegahan terjadinya penyakit tuberkulosis diharapkan peran perawat dan keluarga untuk selalu memberikan motivasi untuk mempercepat proses penyembuhan pasien..
\end{abstract}

Kata kunci : Peran Perawat, Keluarga, Educator, Motivasi, Pasien Tuberkulosis.

\section{PENDAHULUAN}

Tuberkulosis (TB) adalah penyakit infeksi kronis yang masih merupakan permasalahan serius yang di temukan pada penduduk dunia termasuk Indonesia. Penyakit paru yang disebabkan oleh Mycobacterium tuberculosis ini ditemukan telah menginfeksi hampir sepertiga penduduk dunia dan telah menjadi masalah kesehatan utama secara global.

Di Indonesia pada tahun 2016 di temukan jumlah kusus tuberculosis sebanyak 351.893 kasus meningkat, bila dibandingkan semua kasus tuberculosis yang ditemukan pada tahun 2015 yang sebesar 330.729 kasus. Jumlah kasus tertinggi yang dilaporkan terdapat di provinsi dengan jumlah penduduk yang besar yaitu Jawa Barat, Jawa Timur dan Jawa Tengah. Kasus tuberculosis di tiga provinsi tersebut sebesar $44 \%$ dari

Dari tahun ketahun, penyakit tuberculosis (TB) di Kabupaten Bima mengalami peningkatan. Tercatat, di tahun 2017 angkanya sudah mencapai 787 kasus. Penyakit kronis yang menyerang paru-paru tersebut tergolong penyakit sejak jaman dulu. Dan sampai sekarang belum bisa di berantas dengan tuntas. Sebenarnya TB itu bisa di sembuhkan, tapi persoalannya lama, butuh waktu sekitar satu tahun untuk di sembuhkan. Untuk mengatasi penyakit TB perlu adanya motivasi dari tim kesehatan, keluarga dan orang sekitar sebagai pendorong untuk mempercepat proses penyembuhan. jumlah seluruh kasus baru di Indonesia dan di provinsi NTB sebesar 4,14\% kasus dengan urutan ke 12 yang mengalami tuberculosis (Kemenkes RI, 2017). [1]
Data rikesdas di Provinsi NTB, pada tahun 2016 dilaporkan bahwa jumlah seluruh pasien TB (semua tipe) mencapai 5.828 orang, dan sebanyak 3.860 orang diantaranya merupakan kasus baru BTA+. Sedangkan untuk tahun 2017, jumlah seluruh pasien TB adalah 6.644 orang, dengan 4.149 orang merupakan kasus TBA+. Apabila dibandingkan dengan tahun 2016, maka kasus TB pada tahun 2017 mengalami peningkatan sebesar $14,04 \%$.

Penderita TB paru dinyatakan sembuh dengan indicator penderita telah menyelesaikan pengobatannya secara lengkap dan melakukan pemeiksaan ulang dahak (follow-up) dengan hasil negatif pada akhir pengobatan dan pada satu pengobatan follow-up sebelumnya. Motivasi pasien untuk sembuh merupakan bagian dari kekuatan yang berasal dari diri pasien itu sendiri yang akan mendorong perilaku pasien untuk mencapai kesembuhan yang diinginkan. Motivasi pasien yang rendah akan menyebabkan pasien menghentikan pengobatan secara sepihak. Pasien sangat membutuhkan dukungan dan bantuan dari orang lain disekitarnya, dukungan informasi sangat diperlukan pasien untuk mendapatkan petunjuk informasi yang dibutuhkan. Motivasi pasien untuk sembuh mempengaruhi faktor lingkungan rumah sakit, dokter, perawat dan tenaga kesehatan lainnya serta dukungan dari keluarga. Berdasarkan hasil pengumpulan data di Puskesmas Woha pada hari Selasa tanggal 23 bulan April 2019 diperoleh data berjumlah sebanyak 90 penderita TB paru pada tahun 2019. Dan berdasarkan hasil wawancara pada 4 pasien penderita TB 3 diantaranya mengatakan kurang 
mendapat motivasi atau informasi untuk kesembuhan pasien.

\section{METODE PENELITIAN}

Desain yang di gunakan dalam penelitian adalah deskriptif analitik dengan pendekatan cross sectional yaitu pendekatan penelitian yang di lakukan secara simultan atau dilakukan dalam waktu yang bersamaan. Penelitian ini dilaksanakan di Puskesmas Woha Kabupaten Bima. Penelitian ini dilaksanakan pada bulan September - Oktober 2019 di lakukan di Puskesmas Woha Kabupaten Bima. Sampel yang digunakan dalam penelitian ini sebanyak 32 orang. Dengan menggunakan teknik proposive sampling dimana sesuai dengan kriteria yang ditentukan oleh peneliti. Kriteria inklusi: Pasien dalam keadaan sadar dan mampu berkomunikasi, Pasien yang bersedia menjadi responden, Pasien dalam pengobatan di Puskesmas Woha. Kriteria eksklusi: Pasien mengalami kondisi misalnya tidak sadar, Pasien yang tidak bisa bicara, Pasien menolak menjadi responden [2].

\section{HASIL DAN PEMBAHASAN}

\section{Karakteristik responden Umum}

a. Karateristik Umum Responden.

Berdasarkan hasil penelitian yang dilakukan di wilayah kerja puskesmas Woha Kab. Bima dengan 32 responden diperoleh data sebagai berikut :

Tabel 1. Distribusi Frekuensi Responden Berdasarkan Umur

\begin{tabular}{lcc}
\hline Umur & Frek. & \% \\
\hline Remaja Awal (12 - 16 Tahun) & 1 & 3.1 \\
Remaja Akhir (17 - 25 Tahun) & 3 & 9.4 \\
Dewasa Awal (26 - 35 Tahun) & 3 & 9.4 \\
Dewasa Akhir (36 - 45 Tahun) & 9 & 28.1 \\
Lansia Awal (46 - 55 Tahun) & 7 & 21.9 \\
Lansia Akhir (56 - 65 Tahun) & 9 & 28.1 \\
\hline Total & $\mathbf{3 2}$ & $\mathbf{1 0 0}$ \\
\hline
\end{tabular}

Table 1 tentang distribusi responden berdasarkan umur, dari 32 responden, menunjukan bahwa responden yang paling banyak umur 36-45 tahun dan umur 56-65 tahun sebanyak 9 orang $(28,1 \%)$, sedangkan responden yang paling sedikit umur 12-16 tahun sebanyak 1 orang $(3,1 \%)$.

Tabel 2. Distribusi Frekuensi Responden Berdasarkan jenis Kelamin

\begin{tabular}{lrr}
\hline Jenis Kelamin & Frekuensi & \% \\
\hline Laki-Laki & 22 & 68.8 \\
Perempuan & 10 & 31.2 \\
\hline Total & 32 & 100.0 \\
\hline
\end{tabular}

Table 2 tentang distribusi responden berdasarkan jenis kelamin responden, dari 32 responden, menunjukan bahwa jenis kelamin responden yang paling banyak jenis kelamin laki-laki sebanyak 22 orang $(68,8 \%)$, sedangkan jenis kelamin responden yang paling sedikit perempuan sebanyak 10 orang $(31,2 \%)$.

Tabel 3. Distribusi Frekuensi Responden Berdasarkan Peran Perawat

\begin{tabular}{crr}
\hline Peran Perawat & Frekuensi & \multicolumn{1}{c}{$\%$} \\
\hline Negatif & 2 & 6.2 \\
Positf & 30 & 93.8 \\
\hline Total & 32 & 100.0 \\
\hline
\end{tabular}

Table 3 tentang distribusi responden berdasarkan peran perawat, dari 32 responden, menunjukan bahwa peran perawat yang positf sebanyak 30 orang $(93,8 \%)$, sedangkan peran perawat yang negatif sebanyak 2 orang $(6,2 \%)$.

Tabel 4. Distribusi Frekuensi Responden Peran Keluarga

\begin{tabular}{crr}
\hline Peran Keluarga & Frekuensi & \multicolumn{1}{c}{$\%$} \\
\hline Negatif & 6 & 18.8 \\
Positif & 26 & 81.2 \\
\hline Total & 32 & 100.0 \\
\hline
\end{tabular}

Table 4 tentang distribusi responden berdasarkan peran keluarga, dari 32 responden, menunjukan bahwa responden peran keluarga yang positif 26 orang $(81,2 \%)$, sedangkan responden peran keluarga yang negative sebanyak 6 orang $(18,8 \%)$.

Tabel 5. Distribusi Frekuensi Responden Motivasi Sembuh Pasien

\begin{tabular}{crc}
\hline Motivasi Sembuh Pasien & Frekuensi & $\%$ \\
\hline Negatif & 6 & 18.8 \\
Positif & 26 & 81.2 \\
\hline Total & 32 & 100. \\
\hline
\end{tabular}

Table 5 tentang distribusi responden berdasarkan motivasi sembuh pasien tuberkulosis di wilayah kerja puskesmas Woha, dari 32 responden, menunjukan bahwa responden mempunyai motivasi sembuh yang positif sebanyak 26 orang $(81,2 \%)$, sedangkan responden yang mempunyai motivasi sembuh pasien negative sebanyak 6 orang $(18,8 \%)$.

Tabel 6. Hubungan Antara Peran Perawat sebagai educator dengan motivasi sembuh pasien tuberkulosis

\begin{tabular}{|l|c|c|c|c|c|}
\hline \multicolumn{4}{|c|}{ Motivasi Sembuh Pasien } & \multirow{2}{*}{ Jum. } & \multirow{2}{*}{$\rho$} \\
\hline \multirow{4}{*}{$\begin{array}{l}\text { Peran } \\
\text { Perawat }\end{array}$} & \multirow{2}{*}{ Negatif } & 2 & 0 & 2 & \\
\cline { 3 - 5 } & & $6,2 \%$ & $0 \%$ & $6,2 \%$ & \multirow{3}{*}{0,03} \\
\cline { 2 - 5 } & Positf & 4 & 26 & 30 & \\
\cline { 3 - 5 } & & $12,5 \%$ & $81,3 \%$ & 93,8 & \multirow{3}{*}{6} \\
\hline \multirow{2}{*}{ Jumlah } & 6 & 6 & 26 & \\
\cline { 3 - 5 } & $18,7 \%$ & $81,3 \%$ & $100 \%$ & \\
\hline
\end{tabular}


Tabel 6 tentang distribusi responden berdasarkan peran perawat sebagai educator dengan motivasi sembuh pasien tuberkulosis di wilayah kerja puskesmas Woha, peran perawat negatif dengan motivasi sembuh negatif pasien sebayak 2 orang $(6.2 \%)$ dan peran perawat positif dengan motivasi sembuh pasien positf sebanyak 4 orang (12.5\%). Sedangkan peran perawat negatif dengan motivasi sembuh pasien positif tidak ada $(0 \%)$ dan peran perawat positif dengan motivasi sembuh pasien positif sebanyak 26 orang $(81.2 \%)$.

Berdasarkan uji statistic Uji Chi-Square diperoleh nilai $\mathrm{p}=0,03$. Dengan demikian $\mathrm{HO}$ ditolak $\mathrm{Ha}$ diterima atau ada hubungan antara peran perawat sebagai educator dengan motivasi sembuh pasien tuberkulosis

Tabel 7. Hubungan Antara Peran Keluarga sebagai educator dengan motivasi sembuh pasien tuberculosis

\begin{tabular}{|l|c|c|c|c|l|}
\hline \multicolumn{4}{|c|}{ Motivasi Sembuh Pasien } & Jum. & $\rho$ \\
\hline \multirow{4}{*}{$\begin{array}{l}\text { Peran } \\
\text { Perawat }\end{array}$} & \multirow{2}{*}{ Negatif } & Negatif & Positif & & \\
\cline { 3 - 5 } & & $12,5 \%$ & 2 & 6 & \\
\cline { 2 - 5 } & Positf & 2 & 24 & $18,8 \%$ & \\
\cline { 3 - 5 } & & $6,2 \%$ & $75 \%$ & $81,2 \%$ & \multirow{2}{*}{0,006} \\
\hline Jumlah & 6 & 26 & 32 & \\
& & $18,7 \%$ & $81,3 \%$ & $100 \%$ & \\
\hline
\end{tabular}

Tabel 7 tentang distribusi responden berdasarkan peran keluarga sebagai educator dengan motivasi sembuh pasien tuberkulosis di wilayah kerja puskesmas, peran negatif negatif dengan motivasi sembuh negatif pasien sebayak 4 orang (12.5\%) dan peran keluarga positif dengan motivasi sembuh pasien positf sebanyak 2 orang (6.2\%). Sedangkan dari peran keluarga negatif dengan motivasi sembuh pasien positif 2 orang $(6.2 \%)$ dan peran keluarga positif dengan motivasi sembuh pasien positif sebanyak 24 orang $(75 \%)$.

Berdasarkan uji statistic Uji Chi-Square diperoleh nilai $\mathrm{p}=0,006$. Dengan demikian Ho ditolak $\mathrm{Ha}$ diterima atau ada hubungan antar peran keluarga sebagai educator dengan motivasi sembuh pasien tuberculosis.

\section{Pembahasan}

a. Hubungan Antara Peran Perawat Sebagai Educator Dengan Motivasi Sembuh Paisen Tuberkulosis.

Hasil Uji statistic Chi-Square pada hasil penelitian ini diperoleh bahwa ada hubungan antara peran perawat sebagai educator dengan motivasi sembuh pasien. Dimana $p=0,03<0,05$.

Tabel 6 tentang distribusi responden berdasarkan peran perawat sebagai educator dengan motivasi sembuh pasien tuberkulosis di wilayah kerja puskesmas Woha, peran perawat negatif dengan motivasi sembuh negatif pasien sebayak 2 orang (6.2\%) dan peran perawat positif dengan motivasi sembuh pasien positf sebanyak 4 orang $(12.5 \%)$. Sedangkan peran perawat negatif dengan motivasi sembuh pasien positif tidak ada (0\%) dan peran perawat positif dengan motivasi sembuh pasien positif sebanyak 26 orang $(81.2 \%)$.

Hal ini sejalan dengan teori [3] tentang factor yang mempengaruhi kesembuhanpasien maka diperlukan peran perawat sebagai educator untuk memotivasi pasien mencapai kesembuhan melalui pemberian pendidikan kesehatan guna untuk meningkatkan pengetahuan penderita tentang penyakit, cara pengobatan bahaya ketidakteraturan minum obat serta menjaga kondisi tubuh dan memerhatikan kondisi lingkungan sekitar pasien.

Penelitian ini sejalan dengan penelitian yang dilakukan oleh Ria Rohma Wati [4]. Hasil penelitian terdapat hubungan peran perawat sebagai educator dengan motivasi sembuh pasien Tuberculosis paru di ruang rawat inap RS. Paru Kabupaten Jember. Hasil penelitian menunjukan bahwa peran perawat sebagai educator yang terlaksana dengan baik akan memberikan motivasi sembuh yang tinggi yaitu sebesar $68,8 \%$.

Peneliti menganalisa bahwa peran perawat sebagai educator dengan motivasi sembuh pasien tuberkulosis sangat penting. Oleh karena itu, semakin bagus educator yang diberikan perawat kepada pasien dan palayanan kesehatan yang diberikan maka semakin tinggi keinginan pasien untuk cepat penyembuhannya dan semakin tinggi juga mutu pelayanan kesehatan di pandangan masyarakat.

b. Hubungan Peran Kelurga Sebagai Educator

Dengan Motivasi Sembuh Pasien Tuberkulosis

Hasil Uji statistic Chi-Square pada hasil penelitian ini diperoleh bahwa ada hubungan antara peran keluarga sebagai educator dengan motivasi sembuh pasien. Dimana $\mathrm{p}=0,006<0,05$.

Tabel 7 tentang distribusi responden berdasarkan peran keluarga sebagai educator dengan motivasi sembuh pasien tuberkulosis di wilayah kerja puskesmas Woha, peran negatif negatif dengan motivasi sembuh negatif pasien sebayak 4 orang $(12.5 \%)$ dan peran keluarga positif dengan motivasi sembuh pasien positf sebanyak 2 orang (6.2\%). Sedangkan dari peran keluarga negatif dengan motivasi sembuh pasien positif 2 orang $(6.2 \%)$ dan peran keluarga positif dengan motivasi sembuh pasien positif sebanyak 24 orang (75\%).

Hal ini sejalan dengan teori [5]. Motivasi di pengaruhi oleh faktor yang berasal dari dalam dan faktor yang berasal dari luar. Faktor motivasi yang berasal dari dalam didapat dari kekuatan yang memiliki individu, sedangkan faktor yang mempengaruhi motivasi didapat dari keluarga, pengaruh rekan sebaya maupun dukungan dari masyarakat. 
Penelitian ini sejalan dengan penelitian yang dilakukan oleh Tatik Kurnia [6]. Hasil penelitian ini terdapat hubungan peran keluarga dengan tingkat kesembuhan pada penderita TB paru di balai pengobatan penyakit paru-paru unit minggiran Yogyakarta. Ada hubungan yang signifikan antara peran keluarga dengan tingkat kesembuhan pada penderita TB paru.

Peneliti menganalisa bahwa peran keluarga sebagai educator dengan motivasi sembuh pasien tuberkulosis sangat penting. Karena keluarga adalah sumber motivasi yang utama dan keluarga yang selalu memantau kesehatan pasien setiap hari dalam masa pengobatan, semakin tinggi dukungan dari sumber keluarga maka semakin tinggi motivasi pasien untuk sembuh dari penyakitnya.

\section{KESIMPULAN}

Dari hasil penelitian yang dilakukan di wilayah kerja puskesmas Woha tahun 2019 tentang hubungan peran perawat dan keluarga sebagai educator dengan motivasi sembuh pasien tuberkulosis terhadap upaya pencegahan terjadinya penyakit tuberkulosis, dapat disimpulkan bahwa :

1. Tingkat peran perawat sebagai educator dengan motivasi sembuh pasien, menunjukan bahwa responden yang mempunyai motivasi dari 32 responens, menunjukan bahwa peran perawat yang positf sebanyak 30 orang $(93,8 \%)$, sedangkan peran perawat yang negatif sebanyak 2 orang $(6,2 \%)$. Hal ini menunjukan bahwa ada hubungan antara peran perawat dengan motivasi sembuh pasien tuberkulosi, dengan $p$ value $=0,03<0,05$.

2. Tingkat peran keluarga sebagai educator dengan motivasi sembuh pasien, menunjukan bahwa responden yang mempunyai motivasi dari 32 responden, menunjukan bahwa responden peran keluarga yang positif 26 orang $(81,2 \%)$, sedangkan responden peran keluarga yang negatif sebanyak 6 orang $(18,8 \%)$. Hal ini menunjukan bahwa ada hubungan antara peran keluarga dengan motivasi sembuh pasien tuberkulosis, dengan $\mathrm{p}$ value $=0,006<$ 0,05 .

\section{DAFTAR PUSTAKA}

[1] Kementrian Kesehatan Republik Indonesia. 2016. Riset Kesehatan Dasar (Rikesdas), Indonesia. Pusat Data dan Informasi

[2] Sugiyono. 2014. Statistika Untuk Penelitian. Bandung: Alfabeta

[3] Syasra, P. A. 2011. Hubungan Antara Dukungan Sosial Keluarga Dengan Motivasi Kesembuhan Pasien Tuberculosis Di Kota Pekanbaru. Skripsi. Pekanbaru: Universitas Islam Riau
[4] Ria Rohman W, 2015. Hubungan Peran Perawat sebagai educator dengan Motivasi Sembuh Pasien Tuberculosis Paru di Ruang Rawat Inap RS Paru Kabupaten Jember

[5] Syed Zakaria, S.A. 2005. Panduan Dan Strategi Motivasi Diri. Kuala lumpur: Perpustakaan Negara Malaysia

[6] Tatik K, 2015. Hubungan Peran Keluarga Dengan Tingkat Kesembuhan Pada Penderita TB Paru Di Balai Pengobatan Penyakit Paru-Paru Unit Manggirin Yogyakarta 